\title{
Cloning of equine prostaglandin dehydrogenase and its gonadotropin-dependent regulation in theca and mural granulosa cells of equine preovulatory follicles during the ovulatory process
}

\author{
Khampoune Sayasith, Nadine Bouchard, Monique Doré ${ }^{1}$ and Jean Sirois
}

Centre de recherche en reproduction animale and Département de biomédecine vétérinaire, Faculté de médecine vétérinaire, Université de Montréal, 3200 Sicotte, Saint-Hyacinthe, Québec, Canada J2S 7C6 and ${ }^{1}$ Département de pathologie et microbiologie, Faculté de médecine vétérinaire, Université de Montréal, Saint-Hyacinthe, Québec, Canada J2S 7C6

Correspondence should be addressed to K Sayasith; Email: k.sayasith@umontreal.ca

\begin{abstract}
The mammalian ovulatory process is accompanied by a gonadotropin-dependent increase in follicular levels of prostaglandin E2 (PGE2) and PGF2 $\alpha$, which are metabolized by 15-hydroxy prostaglandin dehydrogenase (PGDH). Little is known about ovarian PGDH regulation in non-primate species. The objectives of this study were to characterize the structure of equine PGDH and its regulation in follicles during human chorionic gonadotropin (hCG)-induced ovulation. The full-length equine PGDH was obtained by RT-PCR, $5^{\prime}$ - and $3^{\prime}$-rapid amplification of CDNA ends (RACE). Its open reading frame encodes a 266-amino acid protein that is 72-95\% homologous to other species. Semi-quantitative RT-PCR/Southern blot were used to study PGDH regulation in follicles isolated 0-39 $\mathrm{h}$ post-hCG. Results showed that PGDH mRNA expression was low in follicles obtained at $0 \mathrm{~h}$, increased at 12 and $24 \mathrm{~h}(P<0.05)$, and decreased at 36-h post-hCG. This induction of expression was biphasic, with elevated abundance of transcripts at 12 and $33 \mathrm{~h}$ post-hCG $(P<0.05)$ in mural granulosa and theca cells. Immunohistochemistry and immunoblotting confirmed regulated expression of PGHD protein in both cell types of preovulatory follicles after hCG. High levels of PGDH mRNA were observed in corpus luteum and other non-ovarian tissues tested, except kidney, muscle, brain, and heart. Thus, this study is the first to report the gonadotropin-dependent regulation of PGDH during ovulation in a non-primate species. PGDH induction was biphasic in theca and mural granulosa cells differing from primates in which this induction was monophasic and limited to granulosa cells, suggesting species-specific differences in follicular control of PGDH expression during ovulation.

Reproduction (2007) 133 455-466
\end{abstract}

\section{Introduction}

Prostaglandins (PGs) are potent mediators of several biological processes, including ovulation and inflammation. Their synthesis from plasma membrane arachidonic acid is dependent on the expression of prostaglandin $\mathrm{G} / \mathrm{H}$ synthase (PGHS; also known as cyclooxygenase or COX) and terminal synthases (Sirois et al. 2004), and their regulation can occur at different levels including biosynthesis, receptor, transport, and metabolism. The metabolism of PGs is mediated by nicotinamide adenine dinucleotide $(\mathrm{NAD})^{+}$-dependent 15-hydroxy prostaglandin dehydrogenase $(\mathrm{PGDH}$; also as type-I 15-PGDH), which belongs to the family of short chain dehydrogenase/reductase (SDR) and contains a region of 20 amino acids that is highly conserved within this family of enzymes (Krook et al. 1990). PGDH catalyzes the first step of PG inactivation by cytoplasmic oxidation of the 15-hydroxyl group leading into the generation of 15 keto-metabolites (Ensor \& Tai 1995, Okita \& Okita 1996). This reaction occurs after the uptake of PGs across the plasma membrane by a PG transporter (Nomura et al. 2005). PGDH catalyzes not only the oxidation of PGs under physiological conditions, but also the reduction of 15-keto-metabolites under a lower pH (Yamazaki \& Sasaki 1975). PGDH is ubiquitously expressed in mammalian tissues and can be found in vascular beds, including placenta, lung and kidney, as well as in peripheral tissues, suggesting that local metabolism can also contribute to peripheral regulation of PG activity (Bergholte \& Okita 1986, Mak et al. 1990, Tombach et al. 1990). 
PGDH cDNA has been cloned from several species and organs, including human placenta, mouse lungs, rat intestine, and bovine and porcine uterus (Ensor et al. 1990, Matsuo et al. 1996, Bracken et al. 1997, Zhang et al. 1997, Parent et al. 2006). Human PGDH encodes a protein of 266 amino acids with an apparent molecular weight of $29 \mathrm{kDa}$ (Ensor et al. 1990). Its bioactive form is thought to be a dimer, although some believe that it can function as in a monomer (Hohl et al. 1993, Tai et al. 2006). Sequence alignment of $\mathrm{PGDH}$ from various species indicates that the primary structure of the enzyme is highly homologous, containing a conserved SDR domain, with a C-terminal domain and the region from residue 205 to 224 being more divergent (Tai et al. 2006). PGDH is known to inactivate PGs and, in the lungs, rapid $\mathrm{PGDH}$ inactivation renders primary $\mathrm{PGs}$ at low levels in the plasma (Erwich \& Keirse 1992). In placenta, PGs play a key role in the initiation of parturition in which the expression of $\mathrm{PGDH}$ is decreased and concentrations of PGs are conversely increased at term (Sangha et al. 1994, Winchester et al. 2002). A decrease of PGDH expression is also observed in several cancer tissues and tumor cell lines, including gastrointestinal cancers and colon, lung, and breast carcinomas (Backlund et al. 2005), whereas functional inactivation of $\mathrm{PGDH}$ by genetic deletion increases PGE2 levels in tissues, and blocks production of the urinary PGE2 metabolite (Coggins et al. 2002, Backlund et al. 2005). As PGE2 is associated with resistance to programmed cell death and stimulation of cell migration, cell proliferation and angiogenesis (Sheng et al. 1998, Rozic et al. 2001), a loss of PGDH activity suggests its physiological role as tumor suppressor in cancer tissues. As noted above, little is known about the role of PGDH in the ovulatory process.

Ovulation is an luteinizing hormone (LH)-induced process that involves a series of biochemical and biophysical events, ultimately leading to rupture of the preovulatory follicle and release of the oocyte. This process is accompanied with a selective induction of PGHS-2 in granulosa cells and a marked increase in intrafollicular levels of PGE2 and PGF2 $\alpha$ (Espey 1980, Watson \& Sertich 1990, Sirois \& Doré 1997, Watson \& Hinrichs 1998). Studies on the regulation of PGDH during ovulation are limited to one recent report from the preovulatory follicle of a primate (Duffy et al. 2005). However, studies on the expression and regulation of $\mathrm{PGDH}$ in mares are of interest because preovulatory follicular development and ovulation in this animal species show several distinctive characteristics compared with other species, such as a large diameter of the ovulatory follicle $(40-45 \mathrm{~mm})$, a relatively long ovulatory process (39-42 h), and the follicular rupture at the ovulatory fossa (Stabenfeldt et al. 1975, Duchamp et al. 1987, Ginther 1992, Sirois \& Doré 1997, Kerban et al. 1999, Boerboom et al. 2000). Moreover, the preovulatory rise in gonadotropins in mares causes an extensive expansion of the entire mural granulosa cell layer resulting in abundant accumulation of extracellular matrix (Kerban et al. 1999) that differs from that occurred in rodents in which the expansion process appears primarily limited to the cumulus oocyte complex. The unique and remarkable cellular features observed in equine follicles suggest that the regulation of PGDH may differ in this species. Therefore, the specific objectives of the study were to characterize the primary structure of equine $\mathrm{PGDH}$ and to investigate the gonadotropindependent regulation of $\mathrm{PGDH}$ in equine follicles during the ovulatory process.

\section{Materials and Methods \\ Cloning of the equine PGDH cDNA}

The full-length equine PGDH cDNA was isolated by a combination of RT-PCR, 5'- and 3'-RACE. RT-PCR was first performed using sense and anti-sense primers (primers 1 and 2) designed from a highly conserved region identified after sequence alignments of human (GenBank Accession number, NM_000860) and mouse (GenBank Accession number, NM_008278) PGDH homologues, $100 \mathrm{ng}$ pooled equine ovarian RNA, and a OneStep RT-PCR System (Qiagen) as directed by the manufacturer (Fig. 1Aa). Pooled ovarian RNA consists of equal amounts of RNA prepared from a preovulatory follicle isolated before hCG, another follicle isolated $36 \mathrm{~h}$ after hCG, and a corpus luteum obtained on day 8 of the cycle (day 0, day of ovulation), as described previously (Boerboom et al. 2000). RT-PCR consisted of one cycle of $50{ }^{\circ} \mathrm{C}$ for $30 \mathrm{~min}$ and $95^{\circ} \mathrm{C}$ for $15 \mathrm{~min}$, followed by 35 cycles of $94{ }^{\circ} \mathrm{C}$ for $30 \mathrm{~s}, 60^{\circ} \mathrm{C}$ for $60 \mathrm{~s}$, and $72{ }^{\circ} \mathrm{C}$ for $1 \mathrm{~min}$. The RT-PCR product was subcloned into pGEM-T Easy vector (Promega) and sequenced (Service de Séquençage de I'Université de Laval, Québec, Canada). A large equine PGDH cDNA fragment was obtained.

To characterize the $3^{\prime}$-end of equine PGDH cDNA, a 3'-RACE was performed as described previously (Boerboom et al. 2000) using $5 \mu \mathrm{g}$ total RNA isolated from a preovulatory follicle obtained $36 \mathrm{~h}$ post-hCG. Briefly, reverse transcription was performed using a poly-dT oligonucleotide with anchor sequences at its $5^{\prime}$-end (primer 3) followed by a first PCR done with sense primer 4 and anti-sense 5, and a second nested PCR with sense primer 6 and anti-sense primer 7 (Fig. 1Ab). Primers 4 and 6 were designed from the 3 '-end of a large equine PGDH cDNA fragment.

To obtain the missing $5^{\prime}$-end of equine PGDH cDNA, the 5'-RACE system version 2.0 (Invitrogen Life Technologies) was used as directed by the manufacturer. Reverse transcription was performed as directed using anti-sense primer 8 and $3 \mu \mathrm{g}$ RNA from a 36-h post-hCG preovulatory follicle. The first $5^{\prime}$-RACE/PCR was performed with sense abridged anchor primer 9 (Invitrogen 
A

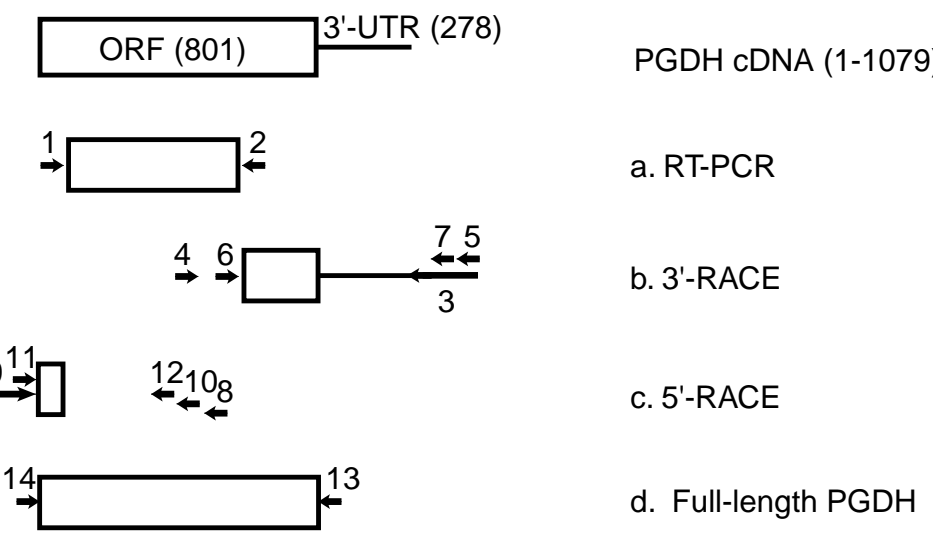

B
1. 5'-AGGTAGCGCTGGTCGATTGCAAT-3'
2. 5'-ATTGGCATCATCGATGGGTCCAA-3'
3. 5'-GTACCGGATCCTCTAGAGAGCTCGTCGACCTCG AGGAATTCAAGCTTTTTTTTTTTTTTTTTTTTT-3'
4. 5'-CTTATGAACAGTGGTGTGAGACTGAA -3'
5. 5'-GTACCGGATCCTCTAGAGAGCTC-3'
6. 5'-TTGGACCCATCGATGATTGCCAAT-3'
7. 5'-GTCGACCTCGAGGAATTCAAGCTT-3'
8. 5'-GCTGCTGAGCGTGTGAA-3'
9. 5'-GGCCACGCGTCGACTAGTACGGGIIGGGIIGGGIIG-3'
10. 5'-CAGGCTGCTGTGCAACAGGAATG-3'
11. 5'-GGCCACGCGTCGACTAGTAC-3'
12. 5'-GATGCCGCCTTCACCTCCATTTT-3'
13. 5'-GCATTCTAGAGATGTTCACTGAGTTTTTGTGTGGAA-3'
14. 5'-CTCGGATCCGCCGCCACCATGGACGTGAACGGCA AAGTGGC-3'

\begin{abstract}
Figure 1 Cloning strategy for isolating the equine PGDH cDNA. (A) The open reading frame (ORF) of equine $\mathrm{PGDH}$ is represented as an open box whereas the $3^{\prime}$-UTR are shown as solid lines; numbers in parenthesis indicate the size in base pairs of equine PGDH ORF and 3'-UTR. The equine PGDH CDNA was characterized by a combination of (a) RT-PCR, (b) 3'-RACE, and (c) 5'-RACE as described in Materials and Methods, and (d) the full-length equine PGDH coding sequence was isolated by RT-PCR; arrows and numbers refer to the orientation, relative position and identity of oligonucleotide primers used in each cloning procedure. (B) List of primers used in section A for equine PGDH cloning. The abridged anchor primer (9) and abridged universal amplification primer (11) are components of the $5^{\prime}$-RACE system (Invitrogen Life Technologies).
\end{abstract}

Life Technologies) and anti-sense primer 10, whereas, the second 5'-RACE/PCR employed the sense abridged universal amplification primer 11 (Invitrogen Life Technologies) and anti-sense primer 12 (Fig. 1Ac). The primers 10 and 12 were designed from the $5^{\prime}$-end of large equine PGDH cDNA fragment. PCRs for both $3^{\prime}-$ and $5^{\prime}$-RACE consisted of 35 cycles of $94{ }^{\circ} \mathrm{C}$ for $30 \mathrm{~s}$, $58{ }^{\circ} \mathrm{C}$ for $60 \mathrm{~s}$, and $72{ }^{\circ} \mathrm{C}$ for $1 \mathrm{~min}$. Final PCR products were subcloned into pGEM-T Easy vector, and sequenced. The complete equine PGDH coding region was isolated by RT-PCR using 100 ng RNA from a 36-h post-hCG preovulatory follicle, and anti-sense primer 13 and sense primer 14 (Fig. 1Ad), subcloned into pcDNA $3.1(+)$ expression vector (Invitrogen Life Technologies) and sequenced.

\section{Equine tissues and RNA extraction}

Equine preovulatory follicles and corpora lutea were isolated at specific stages of the estrous cycle from Standardbred and Thoroughbred mares as previously described (Kerban et al. 1999). Briefly, when preovulatory follicles reached $35 \mathrm{~mm}$ in diameter during estrus, the ovulatory process was induced by injection of hCG (2500 IU, i.v.) and ovariectomies were performed through colpotomy using an ovariotome at $0,12,24,30$, 33,36 , or $39 \mathrm{~h}$ post-hCG ( $n=4-6$ mares/time point). Corpora lutea ( $n=3$ mares) were isolated on day 8 of the estrous cycle. Preovulatory follicles and corpora lutea were dissected from the surrounding ovarian tissues with a scalpel. Follicles were dissected into three cellular preparations referred to as the follicular wall (theca interna with attached granulosa cells), and isolated mural granulosa cells and thecal layers, as described (Sirois et al. 1991). The relative purity of each cellular preparation is estimated to exceed $95 \%$ based on the selective expression of P450 17 $\alpha$-hydroxylase-C17-20 lyase (CYP17A1) and P450 aromatase (CYP19A1) mRNAs by theca interna and granulosa cells respectively (Boerboom et al. 1999). Testicular tissues were obtained from the Hôpital de grandes animaux, Faculté de médecine vétérinaire (Université de Montréal) following a routine castration, whereas, other non-ovarian tissues were collected at a local slaughterhouse. All animal 
procedures were approved by the institutional animal use and care committee. Total RNA was isolated from tissues with TRIzol reagent (Invitrogen Canada, Inc.) according to the manufacturer's instructions using a Kinematica PT 1200C Polytron Homogenizer (Fisher Scientific, Montréal, Canada).

\section{Semi-quantitative RT-PCR and Southern blot analysis}

The semi-quantitative analysis of $\mathrm{PGDH}$ and $\mathrm{rpL} 7 \mathrm{a}$ mRNA levels in equine tissues was performed using a OneStep RT-PCR System as directed by the manufacturer (Qiagen) and sense primer 1 and anti-sense primer 2 (Fig. 1B) specific for equine PGDH (generating a DNA fragment of $445 \mathrm{bp}$ ), and sense (5'-ACA GGA CAT CCA GCC CAA ACG- $\left.3^{\prime}\right)$ and anti-sense (5'-GCT CCT TTG TCT TCC GAG TTG-3') primers specific for equine rpL7a (generating a DNA fragment of $516 \mathrm{bp}$ ). The equine rpL7a primers were designed from a published sequence (GenBank Accession number, AF508309), and its transcript expression has been shown to be relatively constant during the equine ovulatory process (Brown et al. 2004, Sayasith et al. 2005). Each reaction was conducted using $100 \mathrm{ng}$ total RNA, and cycling conditions were one cycle of $50{ }^{\circ} \mathrm{C}$ for $30 \mathrm{~min}$ and $95^{\circ} \mathrm{C}$ for $15 \mathrm{~min}$, followed by 24 PCR cycles of $94{ }^{\circ} \mathrm{C}$ for $30 \mathrm{~s}, 60^{\circ} \mathrm{C}$ for $1 \mathrm{~min}$ and $72{ }^{\circ} \mathrm{C}$ for $2 \mathrm{~min}$ for $\mathrm{PGDH}$, or 18 PCR cycles of $94{ }^{\circ} \mathrm{C}$ for $30 \mathrm{~s}, 58^{\circ} \mathrm{C}$ for $1 \mathrm{~min}$ and $72{ }^{\circ} \mathrm{C}$ for 2 min for rpL7a. The number of PCR cycles used was determined by running a RT-PCR in $50 \mu \mathrm{l}$. A volume of $5 \mu \mathrm{l}$ was pipetted after each three PCR cycles, starting from the 12 th amplification cycle. PCR products were electrophoresed on $2 \%$ TAE-agarose gels, transferred to biotrans nylon membranes (ICN Pharmaceuticals, Montréal, Québec, Canada) and hybridized with corresponding radiolabeled $\mathrm{PGDH}$ and $\mathrm{rpL} 7 \mathrm{a}$ cDNA fragments using QuikHyb hybridization solution (Stratagene, LaJolla, CA, USA). Membranes were exposed to a phosphor screen. Signals were quantified on a Storm imaging system using the ImageQuant software version 1.1 (Molecular Dynamics, Amersham Biosciences) and used to establish a standard curve of amplification in which the number of PCR cycles falling in linear range of amplification corresponding to optimal reactions (exponential amplification) was determined.

\section{Cell cultures, transient transfection, cell extracts and western blot analysis}

An equine granulosa cell line produced in our laboratory (unpublished results) was cultured in Dulbecco's modified Eagle's medium (DMEM)-F12 (Invitrogen Life Technologies) containing L-glutamine, non-essential amino acids, $10 \%$ fetal bovine serum, and penicillin (100 units/ml)-streptomycin $(100 \mu \mathrm{g} / \mathrm{ml})$. Cultures were maintained at $37{ }^{\circ} \mathrm{C}$ in a humidified atmosphere of $5 \%$
$\mathrm{CO}_{2}$, and transiently transfected with $4 \mu \mathrm{g} /$ petris of PGDH expression vector using $30 \mu \mathrm{g}$ LipofectAMINE PLUS reagent in $4 \mathrm{ml}$ DMEM-F12, in accordance with the manufacturer's protocol. Three hours after transfection, cells were rinsed, incubated in culture media for $24 \mathrm{~h}$ and harvested. Protein extracts were prepared as previously described (Filion et al. 2001, Sayasith et al. 2004). Briefly, tissues and cells were homogenized and sonicated on ice in a buffer containing $20 \mathrm{mM}$ Tris $(\mathrm{pH} 8.0), 50 \mathrm{mM}$ EDTA, $0.1 \mathrm{mM}$ diethyldithiocarbamic acid, and $1.0 \%$ Tween (TED buffer). Sonicates were centrifuged at $16000 \mathrm{~g}$ for $15 \mathrm{~min}$ at $4{ }^{\circ} \mathrm{C}$, and the recovered supernatants were stored at $-80^{\circ} \mathrm{C}$. Protein concentration was quantified by the method of Bradford (Bradford 1976, Bio-Rad Protein Assay). Samples (50-100 $\mu \mathrm{g} /$ well) were resolved by one-dimensional SDS-PAGE and electrophoretically transferred to polyvinylidene difluoride membranes. Membranes were incubated with the anti-equine PGDH antibody $(1: 1000$ dilution) or anti-human PGDH antibody (1:200; Cayman Chemical, Gardner, MI, USA). The anti-equine PGDH antibody was commercially produced (New England Peptide, Inc. MA, USA) using an equine PGDH peptide fragment CKAALDEQFEPRKTL to immunize rabbits. Immunoreactive proteins were visualized on Kodak X-OMAT AR film (Eastman Kodak Co., Rochester, NY, USA) after incubation with the horseradish peroxidaselinked donkey anti-rabbit secondary antibody (1:6000) and the enhanced chemiluminescence system (ECL Plus) following the manufacturer's protocol (Amersham Pharmacia Biotech).

\section{Immunohistochemical localization of PGDH in equine follicles}

Immunohistochemical staining was performed using the Vectastain ABC kit (Vector Laboratories, Burlingame, CA, USA), as previously described (Sirois \& Doré 1997). Briefly, formalin-fixed tissues were paraffin-embedded, and $3 \mu \mathrm{m}$ thick sections were prepared and then the paraffin was removed using a series of alcohol concentrations. Endogenous peroxidase was quenched by incubating the slides in $0.3 \%$ hydrogen peroxide in methanol for $30 \mathrm{~min}$. After rinsing in PBS for $15 \mathrm{~min}$, sections were incubated with diluted normal goat serum for 20 min at room temperature. The anti-equine PGDH antibody was diluted in PBS (1:2500) and applied, and sections were incubated overnight at $4{ }^{\circ} \mathrm{C}$. Control sections were incubated with PBS. After rinsing in PBS for $10 \mathrm{~min}$, a biotinylated goat anti-rabbit antibody (1:222; Vector Laboratories) was applied and sections were incubated for $45 \mathrm{~min}$ at room temperature. After washing in PBS for 10 min, sections were incubated with the avidin $\mathrm{DH}$-biotinylated horseradish peroxidase $\mathrm{H}$ reagents for $45 \mathrm{~min}$ at room temperature, washed with PBS for $10 \mathrm{~min}$, and incubated with diaminobenzidine tetrahydrochloride (Sigma) as the chromogen substrate. 
Sections were counterstained with Gill's haematoxylin stain and mounted.

\section{Statistical analysis}

One-way ANOVA was used to test the effect of time after hCG on levels of PGDH mRNA in samples of theca and granulosa cells. PGDH mRNA levels were normalized with the control gene rpL7a prior to analysis. When ANOVA indicated significant differences $(P<0.05)$, the Dunnett's test was used for comparisons of individual means. Statistical analyses were performed using JMP software (SAS Institute, Inc., Carry, NC, USA).

\section{Results}

\section{Characterization of the equine PGDH cDNA}

To clone equine PGDH cDNA, an equine PGDH cDNA fragment of 445-bp was first isolated by RT-PCR using primers designed by sequence alignments of human and mouse PGDH homologues (Fig. 1Aa). Sense and antisense primers designed from the latter cDNA fragment were used in $3^{\prime}$ - and $5^{\prime}$-RACE reactions to characterize the $3^{\prime}$-end and to obtain the missing $5^{\prime}$-end of equine PGDH cDNA (fragments of 543 and 91 bp respectively; Fig. $1 \mathrm{~A} b$ and $\mathrm{A} c$ ). Results showed that the equine PGDH cDNA was composed of an open reading frame (ORF) of $801 \mathrm{bp}$ (including the stop codon), and a $3^{\prime}$-UTR of 278 bp (Fig. 2). The nucleotide sequence was submitted to GenBank with Accession number DQ385611.

The predicted complete coding region of equine PGDH was isolated by RT-PCR, subcloned and confirmed by sequencing. This region encodes a 266 amino acid protein, which is similar in length to human (GenBank Accession number, NM_000860), mouse (GenBank Accession number, NM_008278), fish (GenBank Accession number, XM_689239) and canine (GenBank Accession number, XM_543199), but one amino acid longer than pig (GenBank Accession number, Y07953) and chicken (GenBank Accession number, XM_420526) PGDH homologues (Fig. 2). Comparative analyses indicated that the equine PGDH amino acid sequence is relatively similar to its homologues, ranging from 72 to $95 \%$ identity (Fig. 2). Moreover, structural domains putatively involved in PGDH functions are conserved in the equine protein, including a SDR domain containing active sites for the enzyme, a signal peptide, an asparagine $(\mathrm{N})$-linked glycosylation consensus sequence and amino acids required for $\mathrm{NAD}^{+}$-binding (Fig. 2 (Tai et al. 2006)).

\section{Tissue distribution of equine PGDH mRNA and its regulation in preovulatory follicles}

The distribution of PGDH mRNA in various equine tissues was studied by RT-PCR/Southern blot. Results revealed that levels of $\mathrm{PGDH}$ transcripts were low in kidney, muscle and brain, moderate in heart, and high in the preovulatory follicle isolated $12 \mathrm{~h}$ after hCG and in other non-ovarian tissues tested (Fig. 3A).

The regulation of PGDH mRNA during the ovulatory process was investigated by semi-quantitative RT-PCR/Southern blot using total RNA extracted from follicle walls (theca layers with attached granulosa cells) of equine preovulatory follicles isolated between 0 and $36 \mathrm{~h}$ after hCG treatment, and corpora lutea obtained on day 8 of cycle. Results showed that the expression of PGDH mRNA was low before hCG treatment $(0 \mathrm{~h})$, highly increased at 12 and $24 \mathrm{~h}$, and decreased at 36-h post-hCG (Fig. 3C). Levels of the PGDH transcript were relatively high in corpora lutea (Fig. $3 \mathrm{C}$ ). When results from several follicles $(n=4-6$ distinct follicles (each from different animal) per time point) and corpus luteum $(n=3)$ were expressed as ratios of PGDH to rpL7a, a significant increase of PGDH mRNA at 12 and $24 \mathrm{~h}$ in preovulatory follicles and corpora lutea was observed as compared with $0 \mathrm{~h}$ post-hCG $(P<0.05$; Fig. 3D).

To verify whether equine PGDH mRNA expression is present in granulosa cells and/or theca cells, isolated preparations of both cells were prepared from equine preovulatory follicles and analyzed by RT-PCR/Southern blot. In granulosa cells, results revealed that levels of PGDH mRNA were low at $0 \mathrm{~h}$, increased markedly at $12 \mathrm{~h}$, decreased at 24 and $30 \mathrm{~h}$, increased again at $33 \mathrm{~h}$, and decreased between 36- and 39-h post-hCG (Fig. 4A). When results from several follicles $(n=4-5)$ were expressed as ratios of $\mathrm{PGDH}$ to $\mathrm{rpL} 7 \mathrm{a}$, increased levels of PGDH mRNA were observed after hCG, when compared with $0 \mathrm{~h}$ post-hCG $(P<0.05$; Fig. $4 \mathrm{~B})$. In theca interna layer, results revealed that levels of PGDH mRNA were low at $0 \mathrm{~h}$, increased at $12 \mathrm{~h}$, decreased at $24 \mathrm{~h}$, increased again between 30 and $33 \mathrm{~h}$, and decreased from 36 to $39 \mathrm{~h}$ post-hCG (Fig. 4C). When results from multiple follicles $(n=4-5)$ were expressed as ratios of $\mathrm{PGDH}$ to rpL7a, a marked increase in $\mathrm{PGDH}$ mRNA levels was detected at 12 and $33 \mathrm{~h}$ post-hCG, as compared with $0 \mathrm{~h}$ post-hCG $(P<0.05$; Fig. 4D).

\section{Regulation of PGDH protein in preovulatory follicles}

To determine whether the induction of the PGDH transcript was associated to its protein production in preovulatory follicles, immunoblotting was performed. The specificity of the anti-equine PGDH antibody against $\mathrm{PGDH}$ protein was determined using extracts prepared from granulosa cells overexpressing equine $\mathrm{PGDH}$. Results showed that no protein band was revealed by equine antibody in a mock transfection of granulosa cell (Fig. 5A, lane 1), whereas a single protein band was recognized by the antibody when transfected cell extracts were assayed (Fig. 5A, lane 2). This protein band appears in the range of the calculated molecular mass of the full-length PGDH protein $(29 \mathrm{kDa})$ in the 


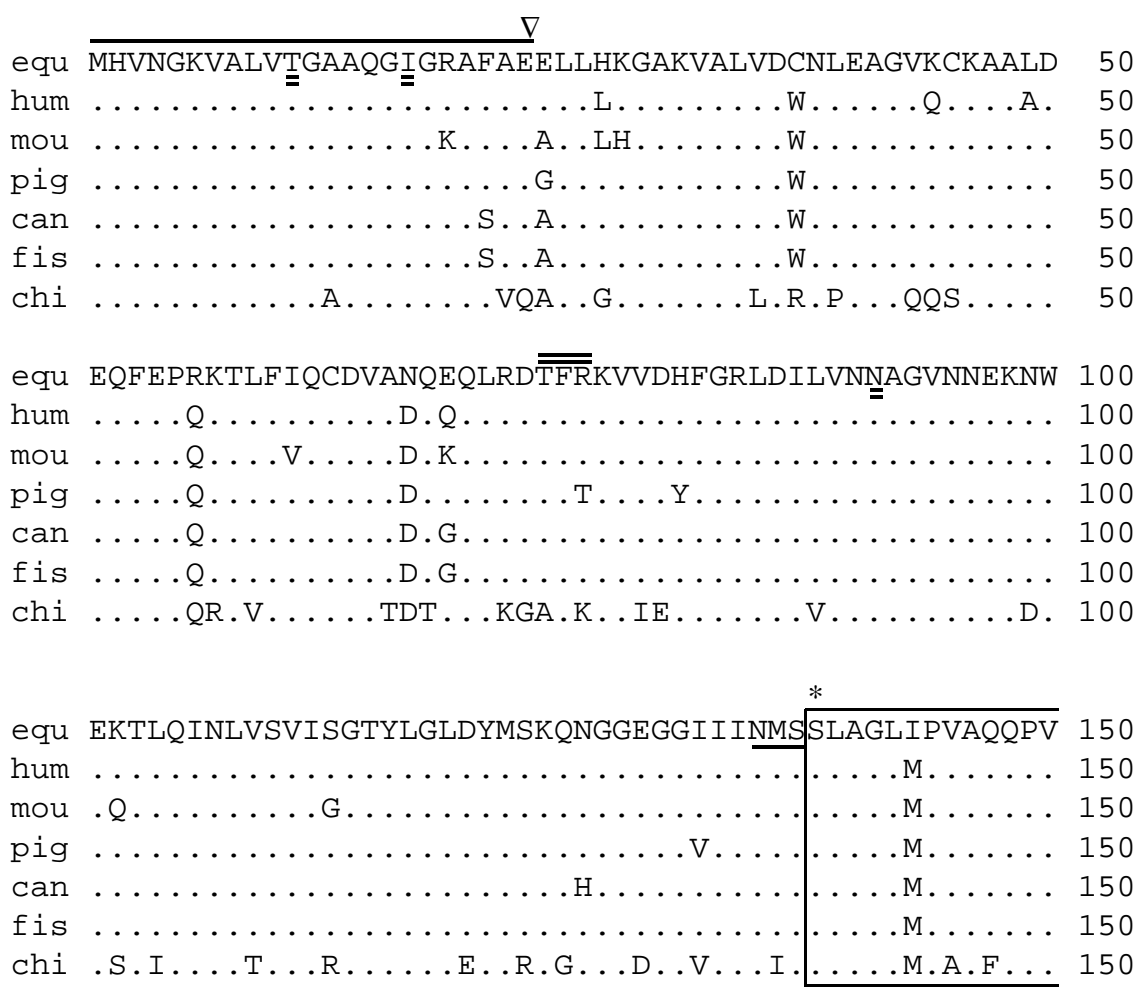

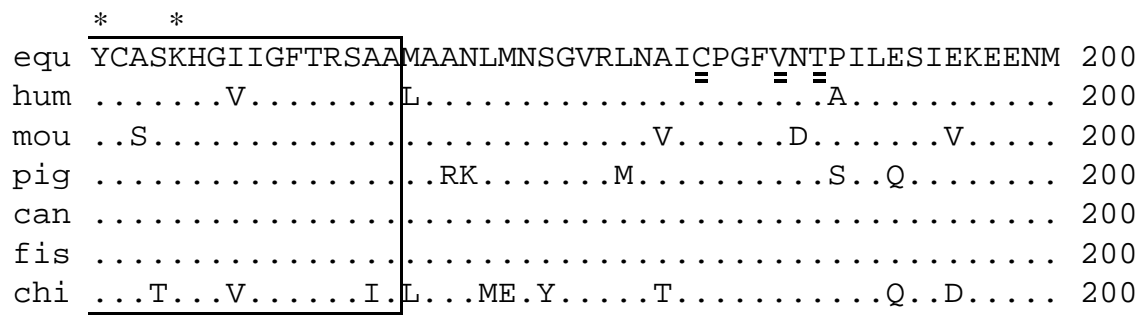

equ GQYIEYKDHIKDMMKFYGILDPSMIANGLITLIEDDALNGAIMKITT $\overline{\overline{T S K}}$ 250

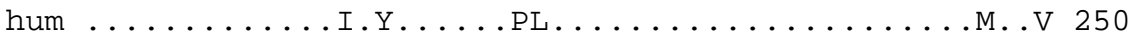

mou ........A.....V.H.A...............SA.E. 250

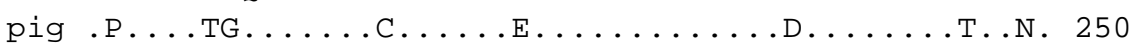

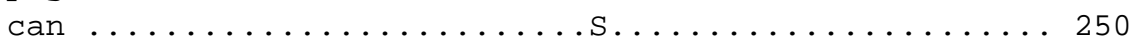

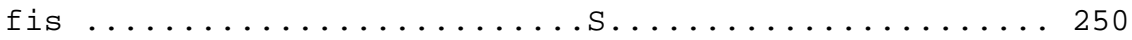

Chi ..YS.......Q..VM...I.E...I...T..EV...A.Q. 250
Figure 2 Deduced amino acid sequence of equine $\mathrm{PGDH}$ and its comparison with other mammalian homologues. The amino acid sequence of equine (equ) $\mathrm{PGDH}$ is aligned with the human (hum), mouse (mou), pig, canine (can), fish (fis), and chicken (chi) homologues. Identical residues are noted with a printed period, hyphens indicate gaps in protein sequences created to optimize alignment, numbers on the right are for the last amino acid residue on that line, and the percentage in parentheses refers to the percentage of identity $(\%)$ in amino acid residues when comparisons are made with equine PGDH. The putative domain of shortchain dehydrogenase/reductase family is boxed, with the active sites identified by an asterisk; the signal peptide and predicted cleavage site are overlined and marked by an empty triangle, respectively; the asparagine (N)-linked glycosylation consensus sequence is underlined; sites for protein kinase $\mathrm{C}$ phosphorylation are double-overlined; and amino acid residues forming $\mathrm{NAD}^{+}$-binding site are double-underlined. absence of post-translational modifications. In parallel, anti-human PGDH antibody (Cayman Chemical, Ann Arbor, MI, USA) known to cross-react with bovine, guinea pig, and baboon PGDH was tested against equine protein extracts to compare with the equine antibody specificity. Similar results were observed when compared with anti-equine PGDH antibody (Fig. 5B). Analyses performed with equine extracts obtained from 


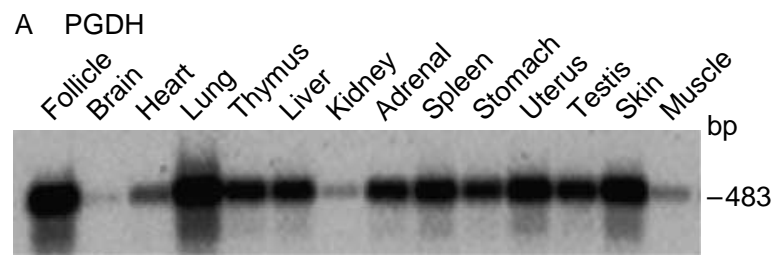

B $\quad \mathrm{rpL} 7 \mathrm{a}$

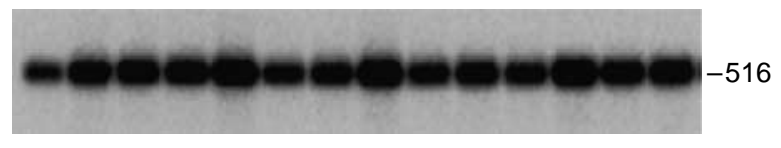

C

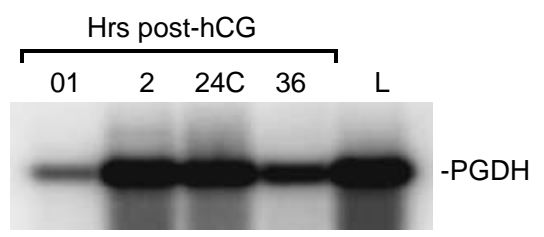

D

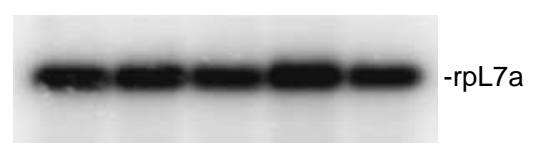

E

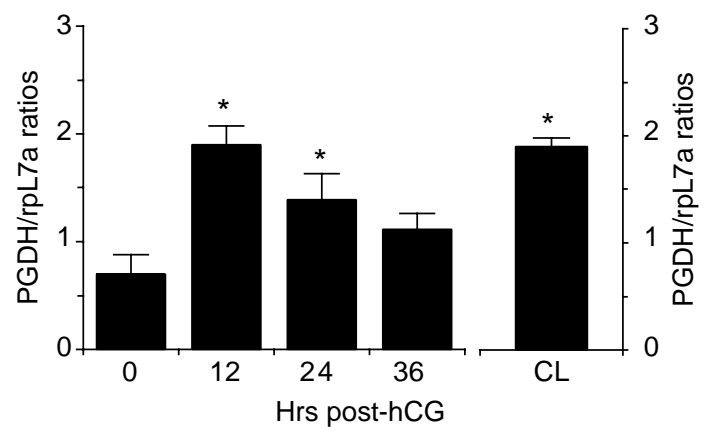

Figure 3 Expression of PGDH mRNA in equine tissues and its gonadotropin-dependent regulation in equine preovulatory follicles. Relative expression of equine PGDH (A) and rpL7a (B; control gene) were analyzed by a semi-quantitative RT-PCR/Southern blot using total RNA (100 ng) extracted from various equine tissues, as described in Materials and Methods. Numbers on the right indicate the size of the PCR fragment in bp. (C-E) RNA extracts were prepared from the wall (theca with attached granulosa cells) of equine preovulatory follicles at $0,12,24$, and $36 \mathrm{~h}$ after administration of an ovulatory dose of hCG, and corpora lutea $(\mathrm{CL})$ isolated on day 8 of the cycle. Samples (100 ng) were analyzed by a semi-quantitative RT-PCR/Southern blot for the expression of $\mathrm{PGDH}$ and rpL7a transcripts, as described in Materials and Methods. Representative results of PGDH (C) and rpL7a (D) mRNA levels are presented from one follicle/time point. (E) The PGDH signal was normalized with the control gene $\mathrm{rpL7a}$, and results are presented as PGDH to rpL7a ratios. Mean \pm s.E.M.; $n=4-6$ distinct follicles, or $n=3 \mathrm{CL}$ (i.e. mares) per time point. Bars marked with an asterisk are significantly different from $0 \mathrm{~h}$ post-hCG $(P<0.05)$. preovulatory follicles isolated 0-36 h after hCG revealed that multiple protein bands were recognized by the equine antibody (Fig. 5C, lanes 2-5) situation, also observed in other species (Schlegel et al. 1974, Ensor \& Tai 1995, Giannoulias et al. 2002): the lower band appears in the range of $29 \mathrm{kDa}$ (a) corresponding to the monomer of full-length PGDH protein; the major band around $60 \mathrm{kDa}$ (b) most likely represent dimeric form of the PGDH protein; and the bands between monomeric and dimeric forms most likely correspond to $\mathrm{PGDH}$ proteins with different extents of glycosylation. A similar protein band pattern was seen with equine testis extracts (Fig. 5D) in keeping with a high abundance of PGDH mRNA detected in this tissue (Fig. 3A). Interestingly, all protein bands followed the similar trend of changes: levels of protein bands were low at $0 \mathrm{~h}$ (Fig. 5C, lane 2) but increased markedly after hCG, with high levels detected at $24 \mathrm{~h}$ post-hCG (Fig. 5C, lanes 3-5); monomeric form of the protein was absent before hCG $(0 \mathrm{~h})$ but highly increased from 12 to $24 \mathrm{~h}$ post-hCG and decreased thereafter. Of note, similar results were also obtained when anti-human PGDH antibody was used (data not shown).

To investigate the intracellular localization of the PGDH protein, immunohistochemistry was performed on sections of equine preovulatory follicles isolated before and after hCG treatment using the anti-equine $\mathrm{PGDH}$ antibody. Results from one representative follicle showed that the intensity of a staining was very low in mural granulosa and theca layers of preovulatory follicles obtained before hCG $(0 \mathrm{~h}$; Fig. $6 \mathrm{~A})$, but high at $12,24,33$, and $36 \mathrm{~h}$ post-hCG (Fig. 6B-E) in both cell types as compared with $0 \mathrm{~h}$. The increase of a staining was accompanied by a progressive loosening (i.e. expansion) of the granulosa cell layer induced by hCG during which PGDH was localized to the cytoplasm of granulosa and theca cells. This increase was correlated with that of $\mathrm{PGDH}$ protein intensity from preovulatory follicular extracts obtained after hCG as demonstrated by immunoblotting (Fig. 5C). As a control of staining, the primary antibody was replaced with PBS and no staining was observed in follicles isolated after hCG (Fig. 6F).

\section{Discussion}

Prostaglandins are known to play important role in the ovulatory process during which levels of PGE2 and PGF2 $\alpha$ are highly increased just prior to ovulation (Espey 1980, Watson \& Sertich 1990, Sirois \& Doré 1997, Watson \& Hinrichs 1998). PGDH is an important enzyme involved in PGE2 and PGF2 $\alpha$ catabolism. There is only one report on the regulation of $\mathrm{PGDH}$ in ovarian physiology of a primate (Duffy et al. 2005). However, the information obtained from animal species does not always reflect the spectrum of potential expression among species. For example, in mares, follicular development and ovulation show several distinct characteristics that are not observed elsewhere: the 
A
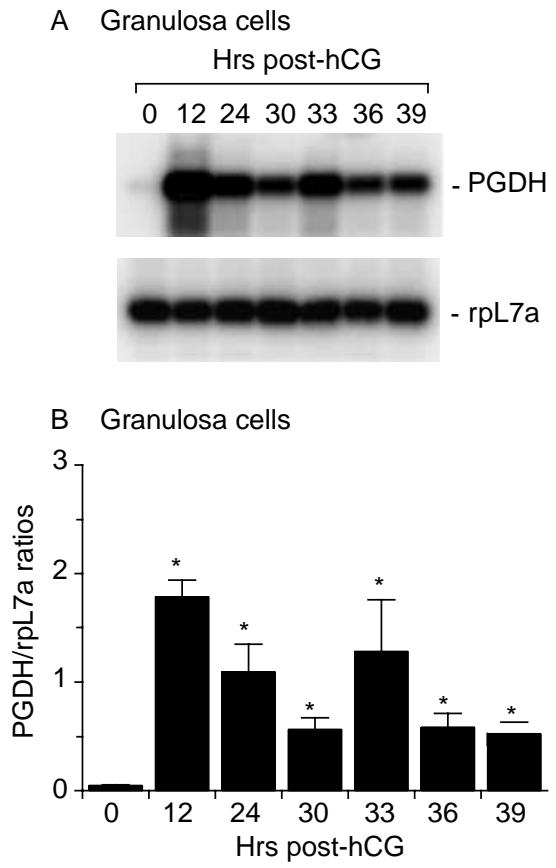

C Theca interna
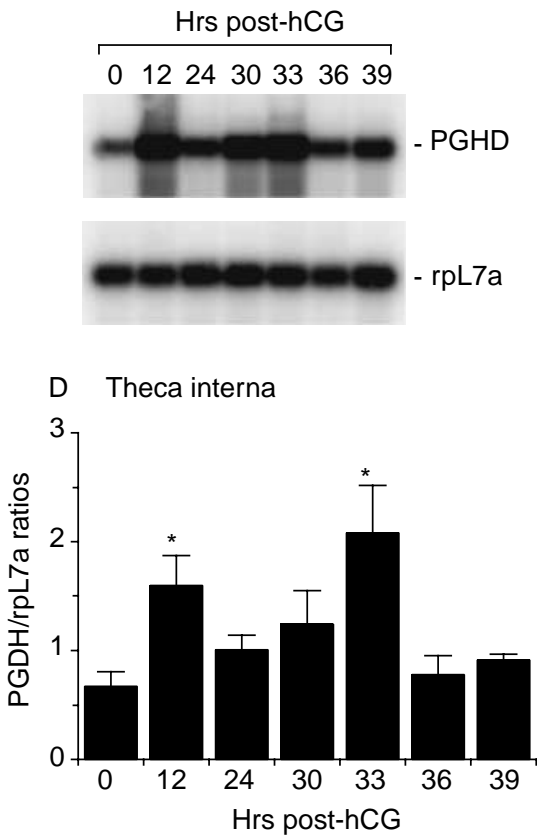

Figure 4 Cellular localization of PGDH mRNA in equine preovulatory follicles. Total RNA was separately extracted from mural granulosa and theca cells isolated from equine preovulatory follicles between 0 and $39 \mathrm{~h}$ post-hCG. Semi-quantitative RT-PCR/Southern blot was performed with these samples (100 ng) to analyze for PGDH and rpL7a content, as described in Materials and Methods. Representative results of PGDH and rpL7a mRNA levels are presented from one granulosa (A) and one theca (C) sample per time point. ( $B$ and $D$ ) The $\mathrm{PGDH}$ signal was normalized to the control gene $\mathrm{rpL} 7 \mathrm{a}$, and results are presented as ratios of PGDH to rpL7a (mean \pm S.E.M.; $n=4-5$ samples (i.e. mares) per time point). Bars marked with an asterisk are significantly different from $0 \mathrm{~h}$ post-hCG $(P<0.05)$. gonadotropin rise in preovulatory follicles induces a unique and remarkable modification of the granulosa cell layer in follicles prior to ovulation, characterized by extensive synthesis and assembly of a viscoelastic extracellular matrix (ECM) within the granulosa cell layer (Kerban et al. 1999) and the spatial and temporal regulation of several genes involved in ovulation and steroidogenesis in preovulatory follicles differs from those observed in the ovary of other mammals (Sirois et al. 1991, Boerboom et al. 1999, Kerban et al. 1999, 2000). This difference in the pattern of gene regulation is further supported by the present study. Indeed, in the primate ovary, PGDH induction occurs in a monophasic manner with a robust induction of $\mathrm{PGDH}$ detected at $12 \mathrm{~h}$ posthCG and a marked decrease from then to ovulation (ovulation occurs around 40-42 h post-hCG in this species) (Duffy et al. 2005). The later induction is restricted only to granulosa cells (Duffy et al. 2005). In contrast, our findings indicate that the expression of gonadotropininduced $\mathrm{PGDH}$ in the mare was biphasic with strong induction observed at 12 and $33 \mathrm{~h}$ after hCG, in both granulosa and theca cells, two main cellular compartments of preovulatory follicles. These differences underline the importance of use of different animal species to determine the physiological importance of genes.

As no previous study on $\mathrm{PGDH}$ regulation has been performed in mares, this study is the first to report that the ovulatory process induced by hCG is accompanied by high levels of $\mathrm{PGDH}$ expression and its regulation in equine preovulatory follicles. $\mathrm{PGDH}$ is the primary enzyme to metabolize PGE2 as well as PGF2 $\alpha$, converting the latter into their 15-keto-derivative metabolites, biologically inactive forms (Tai et al. 2001). Thus, the expression of $\mathrm{PGDH}$ as well as its regulation can be considered as an important regulator of biological fluid PG concentrations that complements their biosynthesis. PGE2 and PGF2 $\alpha$ synthesis is dependent on the PGHS-2 expression, a rate-limiting enzyme for $P G$ synthesis, and terminal synthases, PG E synthase (PGES) and PG F synthase (PGFS) respectively (Sirois et al. 2004), and their biological action is known to mediate through specific receptors, EP1 to EP4 for PGE2 and FP for PGF2 $\alpha$ (Sirois et al. 2004). The obligatory role of PGHS-2 and the PGE receptor EP2 in ovulation has been well established in rodents. Indeed, mice deficient in PGHS-2 or receptor EP2 are infertile and display abnormal ovulation (Lim et al. 1997, Davis et al. 1999, Hizaki et al. 1999, Tilley et al. 1999), which can be restored by an administration of exogenous PGE2 (Davis et al. 1999). In several species, follicular fluid PGE2 and PGF2 $\alpha$ levels rise rapidly after gonadotropin-dependent expression of PGHS-2 in preovulatory follicles (Wong \& Richards 1992, Sirois 1994, Sirois \& Doré 1997). In equine preovulatory follicles, PGHS-2 mRNA expression first became apparent at $30 \mathrm{~h}$ in granulosa cells, reached maximal levels at 33-h post-hCG, and declined thereafter; levels of the PGSH-2 protein were low or undetected from 0 to $30 \mathrm{~h}$, but markedly increased from 33 to $39 \mathrm{~h}$ post-hCG, and high levels of follicular fluid PGE2 and PGF2 $\alpha$ were observed only between 36 and $39 \mathrm{~h}$ post-hCG just before ovulation (Sirois \& Doré 1997, Boerboom \& Sirois 1998). Of note, there is a marked increase of gonadotropin-stimulated PGHS-2 expression that precedes maximal follicular fluid PG levels, suggesting that higher levels of PGs in follicular fluid may be due to the combination of increased PG 
A

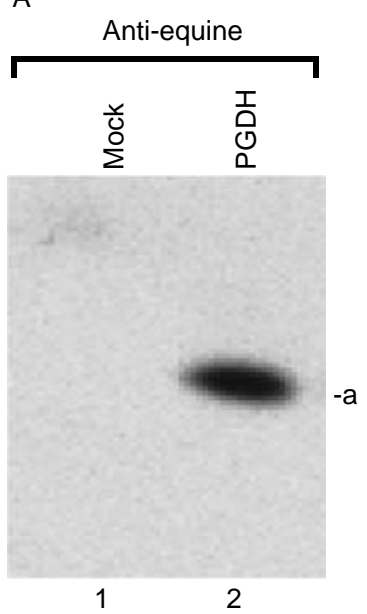

B

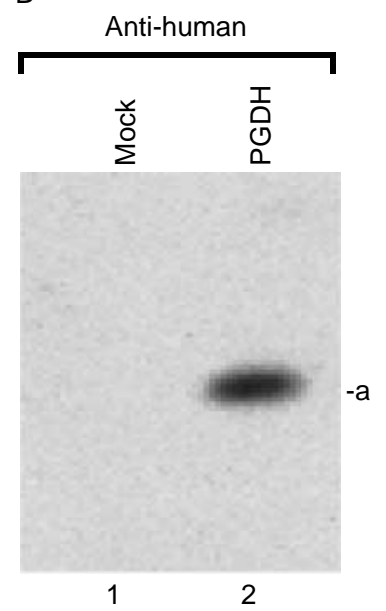

C

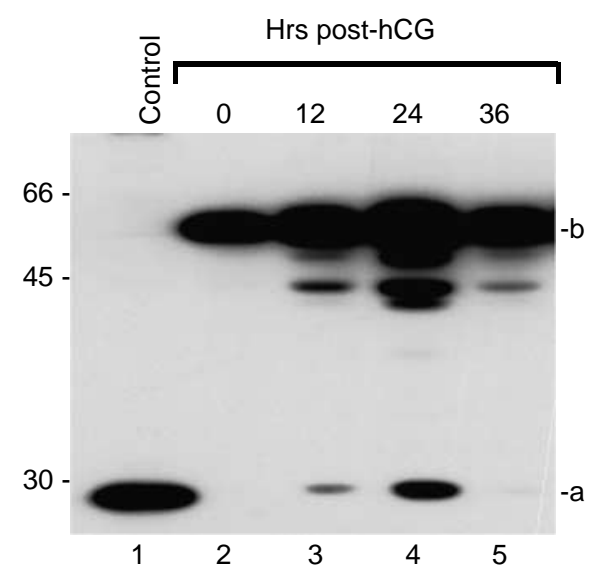

D

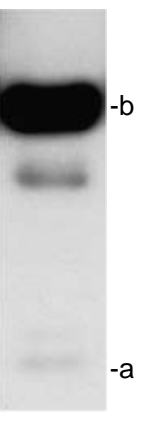

Figure 5 Regulation of PGDH protein in preovulatory follicles. (A and B) Protein extracts were prepared from granulosa cells overexpressing equine PGDH (lane 2), and analyzed by one-dimensional SDS-PAGE and immunoblotting using specific polyclonal antibody raised against a fragment of the equine PGDH protein (A) or anti-human PGDH polyclonal antibody (B). An a letter on the right indicates the migration of PGDH protein; lane 1 is for untransfected cells. (C) Immunoblotting of protein extracts prepared from preovulatory follicles isolated 0-36 $\mathrm{h}$ post-hCG (lanes 2-5), as described in Materials and Methods. Results from protein extracts ( $50 \mu \mathrm{g} /$ well) of one representative follicle/time point are shown ( $n=4$ samples (i.e. mares) per time point). Markers on the left indicate the migration of molecular weight standards. Protein bands indicate multiple forms of PGDH: a lower band is for PGDH monomer (a); a major band is for PGDH dimer (b); and bands between $\mathrm{PGDH}$ monomeric and dimeric forms are for $\mathrm{PGDH}$ proteins with different extent of glycosylation. Lane 1 is for a positive control using protein extracts obtained from granulosa cells overexpressing equine PGDH.

synthesis by PGHS-2 and to decreased PG catabolism by $\mathrm{PGDH}$, since a decrease of $\mathrm{PGDH}$ protein expression is observed at this timing interval. In contrast, low levels of PGE2 and PGF2 $\alpha$ in equine follicular fluid detected from 0 to $33 \mathrm{~h}$ post-hCG may be due to low rate of their synthesis, since gonadotropin-dependent expression of PGHS-2 is very low at this period of time (Sirois \& Doré
1997). However, marked levels of PGDH protein were observed during this time interval, suggesting a possible synthesis of PGDH, since small amount of PGDH mRNA was detected, or a possible induction of PGDH transcripts and their translation simultaneously by hCG at this period of time. Our findings indicate that both granulosa and theca cells express PGDH, suggesting that conversion of PGs by PGHD may occur in both follicular cell types. In all cases, quantification of PGs and their metabolites in follicular fluid during the preovulatory interval will be required to demonstrate the activity of $\mathrm{PGDH}$ to confirm its putative involvement in ovulation.

Gonadotropin-induced expression of phospholipase A2 (cPLA2), the enzyme that mobilizes plasma membrane arachinodic acids for PGHS-2, PGHS-2, and PGES, terminal enzyme for PGE2 synthesis, is well documented in granulosa cells of preovulatory follicles (Sirois 1994, Sirois \& Doré 1997, Filion et al. 2001, Diouf et al. 2006). Our recent studies also have shown that aldo-keto reductase 1C23 (AKR1C23), a multifunctional enzyme believed to possess PGFS-like activity for PGF $2 \alpha$ production, is induced by hCG in equine preovulatory follicles (Brown et al. 2006). Findings from the present study indicate that PGDH is co-localized at identical follicular cells with cPLA2, PGHS-2, PGES, and AKR1C23. Since metabolism of PGs occurs only after their uptake by PG transporter, further studies on the expression and regulation of the PG transporter in follicular cells would be interesting to establish the correlation between the co-expression of biosynthetic, transport, and metabolic proteins in the same preovulatory follicles, and to shed light on the coordinated roles of these proteins in the ovulatory process.

Studies on molecular control of PGDH expression in vivo are limited because most of known PGDH inhibitors either inhibit PGHS-2, consequently inhibit PGE2 synthesis. Numerous reports have shown that $\mathrm{PGDH}$ expression is hormonally regulated in several tissues including ovary, lung, uterus, and reproductive tract (Abel \& Kelly 1983, Tsai \& Einzig 1989, Giannoulias et al. 2002, Winchester et al. 2002). Our data indicate that the expression of PGDH transcripts was low in the kidney, muscle, brain, and heart, but highly detected in corpus luteum and other equine tissues tested. Moreover, the present study identified high/ovulatory levels of gonadotropins as a primary physiological regulator of PGDH in equine preovulatory follicles. Sequence analysis displayed the presence of a cAMP response element and a progesterone receptorbinding site in the human and rodent PGDH promoter region (Matsuo et al. 1997, Greenland et al. 2000). Thus, hCG stimulation through interaction with the $\mathrm{LH} / \mathrm{CG}$ receptor located on follicular cells acting through the classic protein kinase A pathway may regulate PGDH mRNA transcription. The induction of PGDH mRNA in equine preovulatory follicles was biphasic. This suggests the involvement of multiple intracellular factors and 

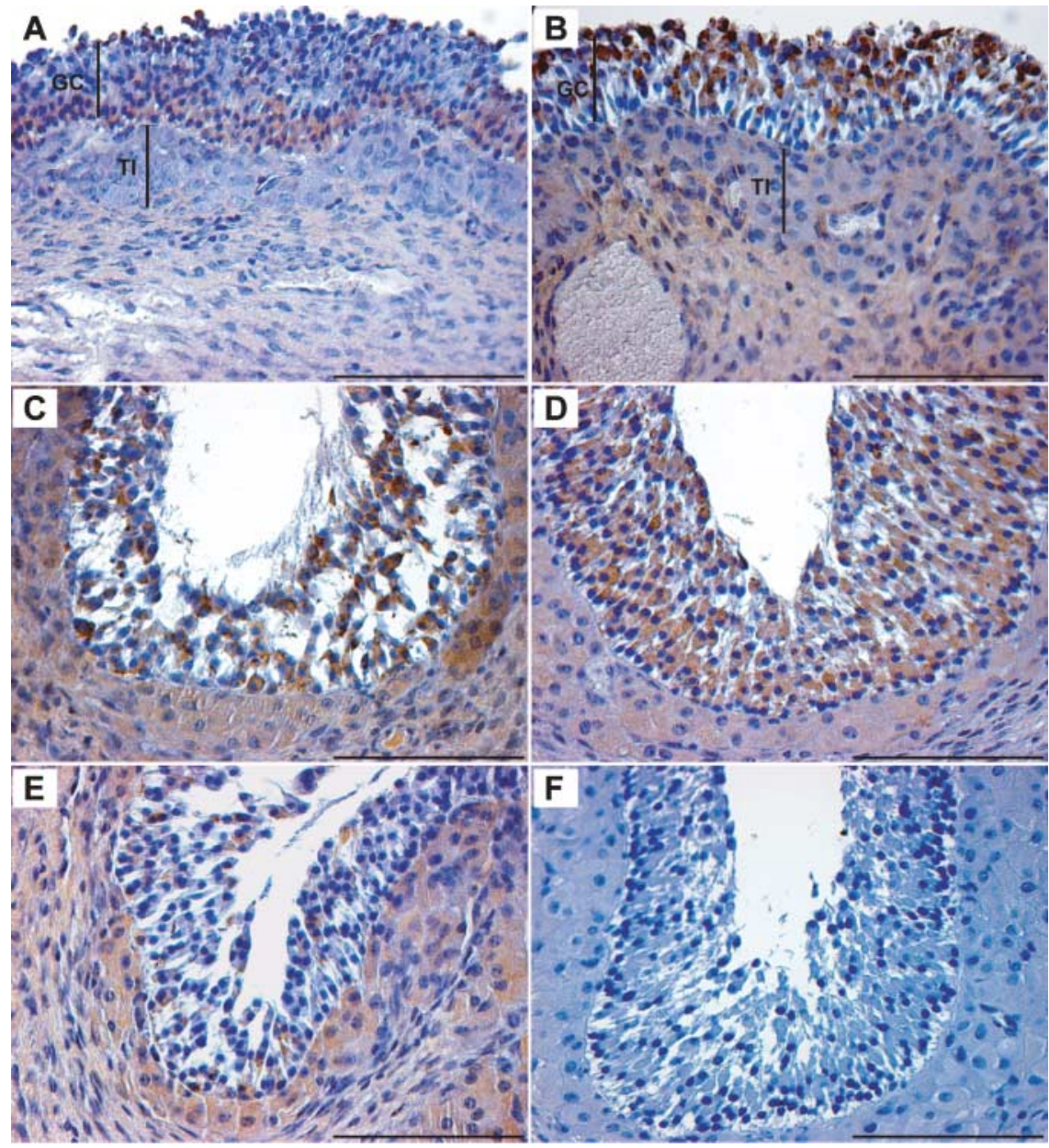

Figure 6 Immunohistochemical localization of $\mathrm{PGDH}$ protein in equine preovulatory follicles. Immunohistochemistry was performed on formalin-fixed sections of preovulatory follicles isolated before and after hCG treatment, as described in Materials and Methods. Results from one representative follicle/time point are shown ( $n=4$ samples (i.e. mares) per time point). These results indicate that PGDH staining in follicles obtained before hCG $(0 \mathrm{~h} ; \mathrm{A})$ was low in granulosa and theca cells, markedly increased in both cell types in preovulatory follicles isolated 12,24 , and $33 \mathrm{~h}$ post-hCG (B, C and D respectively), and slightly decreased at $36 \mathrm{~h}$ post-hCG (E). (F) Control staining from the follicular tissue presented in D (33 h posthCG) was negative when the primary antibody was replaced with PBS. The limits of the granulosa cell (GC) layer are indicated (A and $\mathrm{B})$. The region above the granulosa cell layer is for the antrum, whereas the region immediately beneath corresponds to thecal layers, including the limits of theca interna (TI) (A and B). Magnification, $\times 400$ with a scale bar equal to $0.05 \mathrm{~mm}$. events in the modulation of PGDH, including P4 and its receptor PR. P4 and PR have been shown to stimulate the activity PGDH promoter in the expression of PGDH in myometrial cells (Greenland et al. 2000). Interestingly, P4 and PR are known to be induced by gonadotropins in preovulatory follicles and are required for the follicle rupture and successful ovulation (Watson \& Hinrichs 1998, Robker et al. 2000, Boerboom et al. 2003). Thus, the isolation and characterization of the equine PGDH promoter and studies using P4 inhibitors and PR antagonists would be interesting that should help us to get insight possible involvement of $\mathrm{P} 4$ and $\mathrm{PR}$ in the regulation of $\mathrm{PGDH}$ expression during the ovulatory process of the mares.

In summary, this study reports for the first time the primary structure of equine $\mathrm{PGDH}$ and its regulated expression induced by hCG in equine follicles during the ovulatory process in vivo. In contrast to a primate, in which the induction of PGDH was monophasic and limited only to granulosa cells, the latter induction in equine ovarian follicles was biphasic and occurred in both follicular granulosa and theca cells, suggesting species-specific differences in follicular control of
PGDH expression during the ovulatory process. The expression of $\mathrm{PGDH}$ protein was elevated in preovulatory follicles, but began to decrease at the time when levels of PGHS-2 protein in granulosa cells and of PGE2 and PGF $2 \alpha$ in follicular fluid were concomitantly increased just prior to ovulation. This suggests that $\mathrm{PGDH}$ is involved in the control of PG concentrations required for the ovulatory process. The molecular mechanisms behind the expression of PGDH during this important physiological process in mares and also in other species remain to be clearly determined.

\section{Acknowledgements}

The authors would like to thank Danielle Rannou for her technical help with the immunohistochemistry and Dr Bruce Murphy for his review and constructive criticisms of the manuscript. This work was supported by Natural Sciences and Engineering Research Council of Canada Grant OPG0171135 (to J S). The nucleotide sequence reported in this paper has been submitted to the GenBank/EBI Data Bank with Accession number DQ385611. The authors declare that there is no conflict of interest that would prejudice the impartiality of this scientific work. 


\section{References}

Abel MH \& Kelly RW 1983 Metabolism of prostaglandins by the nonpregnant human uterus. Journal of Clinical Endocrinology and Metabolism 56 678-685.

Backlund MG, Mann JR, Holla VR, Buchanan FG, Tai HH, Musiek ES, Milne GL, Katkuri S \& DuBois RN 2005 15-Hydroxyprostaglandin dehydrogenase is down-regulated in colorectal cancer. Journal of Biological Chemistry 280 3217-3223.

Bergholte JM \& Okita RT 1986 Isolation and properties of lung 15-hydroxyprostaglandin dehydrogenase from pregnant rabbits. Archives of Biochemistry and Biophysics 245 308-315.

Boerboom D \& Sirois J 1998 Molecular characterization of equine prostaglandin $\mathrm{G} / \mathrm{H}$ synthase-2 and regulation of its messenger ribonucleic acid in preovulatory follicles. Endocrinology 139 1662-1670.

Boerboom D, Kerban M \& Sirois J 1999 Dual regulation of promoter IIand promoter $1 \mathrm{f}$-derived cytochrome P450 aromatase transcripts in equine granulosa cells during human chorionic gonadotropininduced ovulation: a novel model for the study of aromatase promoter switching. Endocrinology 140 4133-4141.

Boerboom D, Pilon N, Behdjani R, Silversides DW \& Sirois J 2000 Expression and regulation of transcripts encoding two members of the NR5A nuclear receptor subfamily of orphan nuclear receptors, steroidogenic factor- 1 and NR5A2, in equine ovarian cells during the ovulatory process. Endocrinology 141 4647-4656.

Boerboom D, Russell DL, Richards JS \& Sirois J 2003 Regulation of transcripts encoding ADAMTS-1 (a disintegrin and metalloproteinase with thrombospodin-like motifs-1) and progesterone receptor by human chorionic gonadotropin in equine preovulatory follicles. Journal of Molecular Endocrinology 31 473-485.

Bracken KE, Elger W, Jantke I, Nanniga A \& Gellersen B 1997 Cloning of guinea pig cyclooxygenase-2 and 15-hydroxyprostaglandin dehydrogenase cDNAs: steroid-modulated gene expression correlates to PGF2 secretion in cultured endometrial cells. Endocrinology 138 237-247.

Bradford MM 1976 A rapid and sensitive method for the quantitation of microgram quantities of protein utilizing the principle of protein-dye binding. Analytical Biochemistry 72 248-254.

Brown KA, Boerboom D, Bouchard N, Dore M, Lussier JG \& Sirois J 2004 Human chorionic gonadotropin-dependent regulation of 17beta-hydroxysteroid dehydrogenase type 4 in preovulatory follicles and its potential role in follicular luteinization. Endocrinology 145 1906-1915.

Brown K, Boerboom D, Bouchard N, Doré M, Lussier JG \& Sirois J 2006 Human chorionic gonadotropin-dependent induction of an equine aldo-keto reductase (AKR1C23) with 20alpha-hydroxysteroid dehydrogenase activity during follicular luteinization in vivo. Journal of Molecular Endocrinology 36 449-461.

Coggins KG, Latour A, Nguyen MS, Audory L, Coffman TM \& Koller BH 2002 Metabolism of PGE2 by prostaglandin dehydrogenase is essential for remodeling the ductus arteriosus. Nature Medicine 8 91-92.

Davis BJ, Lennard DE, Lee CA, Tiano HF, Morham SG, Wetsel WC \& Langenbach R 1999 Anovulation in cyclooxygenase-2-deficient mice is restored by prostaglandin E2 and interleukin-1ß. Endocrinology 140 2685-2695.

Diouf MN, Sayasith K, Lefebvre R, Silverside DW, Sirois J \& Lussier JP 2006 Expression of phospholipase A2 group IVA (PLA2G4A) is upregulated by human chorionic gonadotropin in bovine granulosa cells of ovulatory follicles. Biology of Reproduction 74 1096-1103.

Duchamp G, Bour B, Combarnous Y \& Palmer E 1987 Alternative solutions to hCG induction of ovulation in the mare. Journal of Reproduction and Fertility Supplement 35 221-228.

Duffy DM, Dozier BL \& Seachord CL 2005 Prostaglandin dehydrogenase and prostaglandin levels in periovulatory follicles: implications for control of primate ovulation by prostaglandin E2. Journal of Clinical Endocrinology and Metabolism 90 1021-1027.
Espey LL 1980 Ovulation as an inflammatory reaction - a hypothesis. Biology of Reproduction 22 73-106.

Ensor CM \& Tai HH 1995 15-Hydroxyprostaglandin dehydrogenase. Journal of Lipid Mediators and Cell Signalling 12 313-319.

Ensor CM, Yang JY, Okita RT \& Tai HH 1990 Cloning and sequence analysis of the cDNA for human placental NAD+-dependent 15-hydroxyprostaglandin dehydrogenase. Journal of Biological Chemistry 265 14888-14891.

Erwich JJHM \& Keirse MJNC 1992 Placental localization of 15-hydroxy-prostaglandin dehydrogenase in early pregnancy and term pregnancy. Placenta 13 223-229.

Filion F, Bouchard N, Goff AK, Lussier JG \& Sirois J 2001 Molecular cloning and induction of bovine prostaglandin $\mathrm{E}$ synthase by gonadotropins in ovarian follicles prior to ovulation in vivo. Journal of Biological Chemistry 276 34323-34330.

Giannoulias D, Patel FA, Holloway AC, Lye SJ, Tai HH \& Challis JR 2002 Differential changes in 15-hydroxyprostaglandin dehydrogenase and prostaglandin $\mathrm{H}$ synthase (types I and II) in human pregnant myometrium. Journal of Clinical Endocrinology and Metabolism 87 1345-1352.

Ginther OJ 1992 Characteristics of the ovulatory season. In Reproductive Biology of the Mare. pp 173-235. Cross Plaines, WI: Equiservices.

Greenland KJ, Jantke I, Jenatschke S, Bracken KE, Vinson C \& Gellersen B 2000 The human NAD+-dependent 15-hydroxyprostaglandin dehydrogenase gene promotor is controlled by Ets and activating protein-1 transcription factors and progesterone. Endocrinology 141 581-597.

Hizaki H, Segi E, Sugimoto Y, Hirose M, Saji T, Ushikubi F, Matsuoka T, Noda Y, Tanaka T, Yoshida N, Narumiya S \& Ichikawa A 1999 Abortive expansion of the cumulus and impaired fertility in mice lacking the prostaglandin E receptor subtype EP(2). PNAS 96 10501-10506.

Hohl W, Stahl B, Mundkowski R, Hofmann U, Meese CO, Kuhlmann U \& Schlegel W 1993 Mass determination of 15-hydroxyprostaglandin dehydrogenase from human placenta and kinetic studies with (5Z, $8 \mathrm{E}, 10 \mathrm{E}, 12 \mathrm{~S}$ )-12-hydroxy-5,8,10-heptadecatrienoic acid as substrate. European Journal of Biochemistry 214 67-73.

Kerban A, Doré M \& Sirois J 1999 Characterization of cellular and vascular changes in equine follicles during hCG-induced ovulation. Journal of Reproduction and Fertility 117 115-123.

Krook M, Marekov L \& Jörnvall H 1990 Purification and structural characterization of placental $\mathrm{NAD}^{+}$-linked 15-hydroxyprostaglandin dehydrogenase. The primary structure reveals the enzyme to belong to the short-chain alcohol dehydrogenase family. Biochemistry 29 738-743.

Lim H, Paria BC, Das SK, Dinchuk JE, Langenbach R, Trzaskos JM \& Dey SK 1997 Multiple female reproductive failures in cyclooxygenase 2-deficient mice. Cell 91 197-208.

Mak OT, Liu Y \& Tai HH 1990 Purification and characterization of $\mathrm{NAD}^{+}$-dependent 15-hydroxyprostaglandin dehydrogenase from porcine kidney. Biochimica et Biophysica Acta 1035 190-196.

Matsuo M, Ensor CM \& Tai HH 1996 Cloning and expression of the cDNA for mouse $\mathrm{NAD}^{+}$-dependent 15-hydroxyprostaglandin dehydrogenase. Biochimica et Biophysica Acta 1309 21-24.

Matsuo M, Ensor CM \& Tai HH 1997 Characterization of the genomic structure and promoter of the mouse $\mathrm{NAD}^{+}$-dependent 15-hydroxyprostaglandin dehydrogenase gene. Journal of Reproduction and Fertility 235 582-586.

Nomura T, Chang HY, Lu R, Hankin J, Murphy RC \& Schuster VL 2005 Prostaglandin signaling in the renal collecting duct: release, reuptake and oxidation in the same cell. Journal of Biological Chemistry 280 28424-28429.

Okita RT \& Okita JR 1996 Prostaglandin-metabolizing enzymes during pregnancy: characterization of $\mathrm{NAD}^{+}$-dependent prostaglandin dehydrogenase, carbonyl reductase, and cytochrome P450-dependent prostaglandin -hydroxylase. Critical Reviews in Biochemistry and Molecular Biology 31 101-126. 
Parent M, Madore E, MacLaren LA \& Fortier MA 2006 15-Hydroxyprostaglandin dehydrogenase in the bovine endometrium during the oestrous cycle and early pregnancy. Reproduction 131 573-582.

Robker RL, Russell DL, Espey LL, Lydon JP, O'Malley BW \& Richards JS 2000 Progesterone-regulated genes in the ovulation process: ADAMTS-1 and cathepsin L proteases. PNAS 97 4689-4694.

Rozic JG, Chakraborty C \& Lala PK 2001 Cyclooxygenase inhibitors retard murine mammary tumor progression by reducing tumor cell migration, invasiveness and angiogenesis. International Journal of Cancer 93 497-506.

Sangha RK, Walton JC, Ensor CM, Tai HH \& Challis JR 1994 Immunohistochemical localization, messenger ribonucleic acid abundance, and activity of 15-hydroxyprostaglandin dehydrogenase in placenta and fetal membranes during term and preterm labor. Journal of Clinical Endocrinology and Metabolism 78 982-989.

Sayasith K, Bouchard N, Sawadogo M, Lussier JG \& Sirois J 2004 Molecular characterization and role of bovine upstream stimulatory factor 1 and 2 in the regulation of the prostaglandin $\mathrm{G} / \mathrm{H}$ synthase- 2 promoter in granulosa cells. Journal of Biological Chemistry 279 6327-6336.

Sayasith K, Bouchard N, Boerboom D, Brown KA, Dore M \& Sirois J 2005 Molecular characterization of equine P-selectin (CD62P) and its regulation in ovarian follicles during the ovulatory process. Biology of Reproduction 72 736-744.

Schlegel W, Demers LM, Hildebrandt-Stark HE, Behrman RH \& Creep RO 1974 Partial purification of human placental 15-hydroxyprostaglandin dehydrogenase: kinetic properties. Prostaglandins $\mathbf{5}$ 417-433.

Sheng H, Shao J, Morrow JD, Beauchamp DB \& DuBois RN 1998 Modulation of apoptosis and $\mathrm{Bcl}-2$ expression by prostaglandin E2 in human colon cancer cells. Cancer Research 58 362-366.

Sirois J 1994 Induction of prostaglandin endoperoxide synthase-2 by human chorionic gonadotropin in bovine preovulatory follicles in vivo. Endocrinology 135 841-848.

Sirois J \& Doré M 1997 The late induction of prostaglandin G/H synthase-2 in equine preovulatory follicles supports its role as a determinant of the ovulatory process. Endocrinology 138 4427-4434.

Sirois J, Kimmich TL \& Fortune JE 1991 Steroidogenesis by equine preovulatory follicles: relative roles of theca interna and granulosa cells. Endocrinology 128 1159-1166.

Sirois J, Derek B \& Sayasith K 2004 Prostaglandin biosynthesis and action in the ovary. In The Ovary, 2 edn, pp 233-247. Eds PCK Leung \& EY Adashi. Amsterdam: Elsevier Academic Press.

Stabenfeldt GH, Hughes JP, Evans JW \& Geschwind II 1975 Unique aspects of the reproductive cycle of the mare. Journal of Reproduction and Fertility Supplement 23 155-160.
Tai HH, Ensor CM, Tong M, Zhou H \& Yan F 2001 Prostaglandin catabolizing enzymes. Prostaglandins \& Other Lipid Mediators 68-69 483-493.

Tai HH, Cho H, Tong M \& Ding Y 2006 Ding Y NAD+-linked 15-hydroxyprostaglandin dehydrogenase: structure and biological functions. Current Pharmaceutical Design 12 955-962.

Tilley SL, Audoly LP, Hicks EH, Kim HS, Flannery PJ, Coffman TM \& Koller BH 1999 Reproductive failure and reduced blood pressure in mice lacking the EP2 prostaglandin E2 receptor. Journal of Clinical Investigations 103 1539-1545.

Tombach B, Kusseler R \& Schlegel W 1990 Purification of human placental prostaglandin 15-hydroxydehydrogenase. Journal of Chromatography $\mathbf{5 2 1}$ 231-238.

Tsai MY \& Einzig S 1989 Prostaglandin catabolism in fetal and maternal tissues: a study of 15-hydroxyprostaglandin dehydrogenase and 13 reductase with specific assay methods. Prostaglandins, Leukotrienes, and Essential Fatty Acids 38 25-30.

Watson ED \& Hinrichs K 1998 Changes in the concentrations of steroids and prostaglandin $\mathrm{F}$ in preovulatory follicles of the mare after administration of hCG. Journal of Reproduction and Fertility 184 557-561.

Watson ED \& Sertich PL 1990 Secretion of prostaglandins and progesterone by cells from corpora lutea of mares. Journal of Reproduction and Fertility 88 223-229.

Winchester SK, Imamura T, Gross GA, Muglia LM, Vogt SK, Wright J, Watanabe K, Tai HH \& Muglia LJ 2002 Coordinate regulation of prostaglandin metabolism for induction of parturition in mice. Endocrinology 143 2593-2598.

Wong WY \& Richards JS 1992 Induction of prostaglandin H synthase in rat preovulatory follicles by gonadotropin-releasing hormone. Endocrinology 130 3512-3521.

Yamazaki M \& Sasaki M 1975 Formation of prostaglandin E1 from 15-ketoprostaglandin E1 by guinea pig lung 15-hydroxyprostaglandin dehydrogenase. Journal of Reproduction and Fertility $\mathbf{6 6}$ 255-261.

Zhang H, Matsuo M, Zhou H, Ensor CM \& Tai HH 1997 Cloning and expression of the cDNA for rat $\mathrm{NAD}^{+}$-dependent 15 -hydroxyprostaglandin dehydrogenase. Gene 188 41-44.

Received 13 September 2006

First decision 30 October 2006

Accepted 16 November 2006 